Relations industrielles

Industrial Relations

\title{
La noblesse du travail
}

Labor's Dignity

\section{Pie XII}

Volume 1, numéro 2, octobre 1945

URI : https://id.erudit.org/iderudit/1023897ar

DOI : https://doi.org/10.7202/1023897ar

Aller au sommaire du numéro

\section{Éditeur(s)}

Département des relations industrielles de l’Université Laval

\section{ISSN}

0034-379X (imprimé)

1703-8138 (numérique)

Découvrir la revue

Citer cet article

Pie XII (1945). La noblesse du travail. Relations industrielles / Industrial Relations, 1(2), 1-1. https://doi.org/10.7202/1023897ar

Tous droits réservés @ Département des relations industrielles de l’Université Laval, 1945
Ce document est protégé par la loi sur le droit d'auteur. L’utilisation des services d'Érudit (y compris la reproduction) est assujettie à sa politique d'utilisation que vous pouvez consulter en ligne.

https://apropos.erudit.org/fr/usagers/politique-dutilisation/ 


\title{
Bulletin des Relations Industrielles
}

\author{
PUBLIÉ PAR LE DÉPARTEMENT DES RELATIONS INDUSTRIELLES \\ DE LA FACULTÉ DES SCIENCES SOCIALES DE LAVAL, QUÉBEC
}

Abonnement : $\$ 1.50$ la série de 10 numóros

Secrétaire de la rédaction : Jean-Pierre Després

15 octobre 1945

Numéro 2

Dans ce numéro:

L'aspect légal du salaire dans le Québec $\ldots \ldots \ldots \ldots \ldots \ldots \ldots \ldots \ldots$

Ś́curité syndicale.
In this issue:

2

\section{LA NOBLESSE DU TRAVAIL}

« Qui veut que l'étoile de la paix se lève et se repose sur la société doit donner au travail la place que Dieu lui a marquée dès l'origine. Comme moyen indispensable de conquête du monde, moyen voulu par Dieu pour sa gloire, tout travail possède une dignité inaliénable et, en même temps, un lien étroit avec le perfectionnement personnel, noble dignité et prérogative du travail, que ne dépriment ni la peine ni le fardeau qu'il faut accepter comme conséquence du péché originel, en esprit de soumission et d'obéissance à la volonté de Dieu.

"Qui connaît les grandes Encycliques de Nos prédécesseurs et Nos précédents messages sait que l'Église n'hésite pas à tirer les conclusions pratiques qui dérivent de la noblesse morale du travail et à les soutenir de tout le poids de son autorité. Ces exigences comprennent, outre un juste salaire suffisant aux nécessités de l'ouvrier et de sa famille, la conservation et le perfectionnement d'un ordre social qui rende possible et assurée, si modeste qu'elle soit, une propriété privée à toutes les classes du peuple, qui favorise une formation plus relevée pour les enfants des classes ouvrières spécialement doués d'intelligence et de bonne volonté, qui encourage le zèle et l'exercice pratique de l'esprit social dans l'entourage, dans le pays, dans la province, dans le peuple et dans la nation, qui, atténuant les heurts d'intérêts et de classes, ôte aux ouvriers l'impression d'être tenus à l'écart et leur procure l'expérience réconfortante d'une solidarité véritablement humaine et chrétiennement fraternelle. 》)

\section{S. S. Pie XII}

aux délégués du Congrès national de l'Action catholique de l'Italie.

\section{LABOR'S DIGNITY -}

"Workers... It is not by chance but by the deep, ineffable design of God that you find yourselves just simple workers. Mary, the virgin mother of a working family, Joseph, the father of a working family, the shepherds guarding flocks, and finally the wise men from the East - they are all workers - manual workers, watchmen by night, students. They bow down and adore the Son of God who, by His own sympathetic and loving silence, more telling than speech, explains to them all the meaning and the worth of labor.

( Labor is not merely the fatigue of body without sense or value; nor is it merely a humiliating servitude. It is a service of God, a gift of God, the vigor and fullness of human life, the gage of eternal rest. Lift up your heads, and hold them up, workers ! Look at the Son of God who, with His eternal Father, created and ordered the universe ; becoming man like us, sin alone excepted, and having grown in age, $\mathrm{He}$ enters the great community of workers; in His work of salvation $\mathrm{He}$ labors, wearing out His earthly life.

( It is He, the Redeemer of the world who, by His grace which runs through our being and our activity, elevates and ennobles every honest work, be it high or low, great or little, pleasant or tiresome, material or intellectual, giving it a meritorious and supernatural value in the sight of God and thus gathering every form of multifarious human activity into one constant act of glorifying $\mathrm{His}$ father who is in heaven. )

PIUUs XII. 